\title{
A könyvtárak az új digitális világban
}

\author{
Csík Tibor \\ Eötvös Loránd Tudományegyetem Könyvtár- és Információtudományi Intézet \\ csik.tibor@btk.elte.hu \\ ORCID 0000-0003-2061-1506
}

\begin{abstract}
Tibor Csík: Libraries in the new digital world

According to Umberto Eco, books share their fates with their readers. Carrying the idea forward, not only books but also libraries share their fates with their readers. The state of a society is well illustrated by the state of its libraries and how to access information resources. The aim of the presentation is to examine the impact of libraries and their services on the neoliberal economic environment and the expanding process of commodification. Nicholas Negroponte (MIT) stated in 2010 that the physical book will be dead in five years. Although his provocative forecast has not been confirmed, the ratio of online resources in the acquisition of libraries is increasing. Technology companies have approached libraries to digitize their printed collection. Then the digital contents were sold, or used in accordance with their commercial interests to expand the advertising network. Information companies offered e-journals in large bundles for sale to libraries. Despite their promise, the price of digital publications has not become cheaper, but prices have risen steadily. The economic crisis of the early 2000s led to the closure of many public libraries. However libraries cannot become an information soup kitchen, where equal access to data and information hides the fact that there is inequality in access to meaningful information or important knowledge. The tasks of teaching library is not only to teach library and research skills, navigation on web, information retrieval from databases and how acting a law-abiding information consumer. Libraries can teach about information production and current information economics in part of information literacy. Libraries play a role in electronic publishing through their digital collections and repositories.
\end{abstract}

Keyword: library services, content industry, digitisation, e-lending, commodification 
Umberto Eco A rózsa neve címú múvében található az a gondolat, mely szerint a könyvek osztoznak olvasóik sorsában. Továbbvíve a gondolatot az olvasók sorsában nemcsak a könyvek, hanem a könyvtárak is osztoznak, tehát a társadalom viszonyait jól jellemezi könyvtárainak helyzete: hogyan lehet az információforrásokhoz hozzáférni, milyen tudástárak állnak a köz és a különböző közösségek rendelkezésére. Az ezredfordulóra végbement alapvető változások következtében, a kulturális és a szellemi élet intézményrendszerében a redisztribúció és a reciprocitás egyre jelentéktelenebbé válik, miközben a kulturális és szellemi javak elérésében, megosztásában szélesedik a kommodifikáció folyamata.

A könyvtárak folyamatosan megújulva, a digitális technológiák fölhasználásával akarták szolgálni a közösségek, illetve a társadalom egészének információellátását. A tartalom-eloállítás és -forgalmazás gazdasági modelljének átalakulásával a kiadók és az információtechnológiai cégek a könyvtárakra egyre inkább úgy tekintettek, mint kiaknázandó forrásokra vagy a profitot csökkentő tényezőkre. Tanulmányunkban, két fontos terület, a könyvtárak gyüjteményében és szolgáltatásaiban végbement változásokat kívánjuk bemutatni. A téma összetettsége és a terjedelmi korlátok miatt a legmeghatározóbb szempontok tárgyalására törekedhetünk.

\section{A tudásmegosztás szolgálatába állított technológia}

A XIX. század végének, illetve a XX. század első harmadának, a társadalmi és a tudományos haladásban hívő gondolkodói megvalósíthatónak vélték a tudás egyetemes megosztását. Közülük is kiemelkednek a dokumentációs mozgalom megindítói, Paul Otlet (1868-1944) és Henri La Fontaine (1854-1943), akik 1895-ben kezdeményezték az emberi tudást magukban foglaló kiadványok egyetemes számbavételét (Repertoire bibliographique universel - RBU) és gyűjteménnyé szervezését. ${ }^{1}$ 1930-as évekre a tudásmegosztás valamennyi formáját kidolgozták az „analóg” technológiára alapozva.

A szellemi javak egyetemes gyűjteményének eszméje ma is hat. Az ezredfordulót követő első évtized közepén kezdeményezték például a Digitális Világkönyvtár (World Digital Library - WDL) fölállítását, amely ma, több mint 190 ország közel 200 intézménye közremúködésével épül, s az UNESCO és a Library of Congress (Egyesült Államok) üzemelteti. ${ }^{2}$ A nyílt tudomány (Open Science) koncepciójának kialakítása az Európai Unióban a stratégiai célok közé tartozik, ${ }^{3}$ az UNESCO-ajánlás a nyílt tudományról pedig éppen most van születőben. ${ }^{4}$ Valamennyi felfogás épít a könyvtárakra, számít a közremúködésükre.

1 Rayward, Boyd W. „Visions of Xanadu: Paul Otlet (1868-1944) and hypertext.” JASIS. 45. 4. sz. (1994) 235-250. Hozzáférés: 2021. 0406 https://doi.org/10.1002/(SICl)10974571(199405)45:4<235::AID-ASI2>3.0.CO;2-Y; https://web.archive.org/web/20051227184732/ http://people.lis.uiuc.edu/ wrayward/otlet/xanadu.htm

2 World Digital Library honlapja: https://www.wdl.org/en/ Hozzáférés: 2021. 04. 06.

3 „Open innovation, open science, open to the world - a vision for Europe.” https://ec.europa. eu/digital-single-market/en/news/open-innovation-open-science-open-world-vision-europe Hozzáférés: 2021. 0406.

4 UNESCO. „Recommendation on Open Science.” https://en.unesco.org/science-sustainable-future/ open-science/recommendation Hozzáférés: 2021. 0406. 


\section{A digitális forma megtöltése tartalommal}

A XX. századra a könyv metaforává vált, jelképezte a már meghaladott tudásrögzítési és megosztási technológiákat és a meghaladni kívánt ismereteket is. Thomas A. Edison, a feltaláló 1913-ban úgy ítélte meg, hogy a könyvek hamarosan elavulnak az állami iskolákban. Marshall McLuhan, a forrómédiumok apostola, nemcsak a Gutenberggalaxis végét hirdette meg, hanem a könyvet ugyanolyan mulandónak tekintette, mint a szabásmintát vagy a csíkot a női harisnyán. Nicholas Negroponte, a digitális létezésünk kutatója 2010-ben arról beszélt, hogy a könyv mint tárgy öt év múlva halott lesz.

A számítógépes technológia a könyvtárak életében az 1950-es években jelent meg. A szakirodalom visszakereshetővé tétele érdekében a bibliográfiákból, a katalógusokból, a referáló-indexelő kiadványokból számítógépes adatbázisokat építettek. Az orvostudomány szakirodalmát feldolgozó - National Library of Medicine (NLM US) készítette - Index Medicus kiadványból az 1960-as évek közepétől a bibliográfiai adatbázis vált, mely 1971-től online kereshető (MEDLINE), 1990-es évek második felétől a világhálón elérhető, s már teljes szöveget is tartalmazó adatbázissá alakították (PubMed). A fejlesztés mögött kormányzati stratégia állt, s bőséges szövetségi (pl. National Institutes of Health - NIH) és vállalati anyagi forrásokkal. Ennek eredményeként ma az Egyesült Államok szakirodalmi adatbázisai jelentik a vonatkoztatási pontot a tudományos élet számára.

Hazánkban is megindult a bibliográfiák, dokumentációs és referáló kiadványok stb. adatbázissá alakításának folyamata. Például az Országos Pedagógiai Könyvtár nemzeti szakbibliográfiájából (Magyar Pedagógiai Irodalom) és referáló lapjából (Külföldi Pedagógiai Információ ) 1989-től számítógépes adatbázis épül, amely 2007től folyóiratok hivatkozásait is feldolgozza. A magyar szakirodalmi adatbázisok - a tudományos szakkönyvtárak térvesztésével párhuzamosan - az 1990-es évektől folyamatosan hanyatlanak, szűnnek meg. Sikeres viszont az 1990-es évek második felétől a hazai könyvtárak katalógusainak adatbázissá szervezése és online elérhetővő tétele.

\section{Digitalizálás}

A könyvtárak remek lehetőséget láttak a digitális technológiában arra, hogy kiteljesítve küldetésüket a gyűjteményüket is mind szélesebb kör számára tegyék elérhetővé. A digitalizálás tömegessé válása és az abból profitot termelő vállalkozások megjelenése azonban teljesen új helyzetet teremtett. Például a 2000-es évek elején az amerikai nagykönyvtárak anyagát (pl. Harvard Library, New York Public Library) a Google - a Google Print Program keretében - eddig nem látott mértékben digitalizálta, s tette a tartalmakat a szolgáltatása részévé. A Bibliothèque nationale de France élesen elutasította a „kedvező” digitalizálási lehetőséget, mert a francia kulturális örökség megőrzését és közzé tételét nemzeti feladatnak tekintette. A Google digitális könyvtári 
terveit az amerikai szerzői jogi (Authors Guild) és a kiadói szervezet (Association of American Publishers) bíróságon támadta meg. ${ }^{5}$

A könyvtárak az 1990-es évek közepétől aktívan bekapcsolódnak a digitális megőrzési programokba, melyek az ezredfordulót követően lendültek föl, s amelyeket támogat az UNESCO és a nemzetközi könyvtárosszervezet, az IFLA. ${ }^{6}$ Az Egyesült Államokban a nemzeti könyvtár (Library of Congress) teveivel az 1990-es évek végén indult a folyamat, majd 2010-től a kongresszus támogatta nemzeti programmal folytatódott (National Digital Information Infrastructure and Preservation Program - NDIIPP), 2010-től az intézményi kört szélesítik (National Digital Stewardship Alliance - NDSA), 2016-tól már digitális könyvtárak szövetségében (Digital Library Federation - DLF) folyik a munka. ${ }^{7}$ A kis nemzetek könyvtári rendszere is nagyon lelkesítő példával tud szolgálni. Ilyen lehet a norvég nemzeti könyvtár (Nasjonalbiblioteket) stratégiája, mely online elérhető digitális könyvtár létrehozását célozza. ${ }^{8}$

A stratégiai tervezettséghez képest a másik végletet az állományvédelmi szükségintézkedésként megvalósuló digitalizáció képviseli, melyet csak úgy tud a könyvtár elvégeztetni, ha lemond a tartalom online terjesztésről a digitalizáló cég javára. Az eredményes nemzeti program nem nélkülözheti a megbízható és hosszú távon alkalmazható technológiát, az intézmények széles körét átfogó, jól szervezett együttműködést, a digitalizálandó művek tervszerű kiválasztását és a folyamatos munkát lehetővé tevő, biztos pénzügyi hátteret.

A digitális kiadványok és a könyvtárak, avagy az Amazonnak megvan a hatalma ahhoz, hogy a könyvtárakat a XX. században tartsa9

A könyvtárak beszerzésében nagy változást hoztak a hordozó nélküli, elektronikus/ digitális dokumentumok $A$ költségvetésben az időszaki kiadványok beszerzésére fordított összegek emelkedtek a leginkább. A felsőoktatási könyvtáraknál - az amerikai

5 The Authors Guild. „Authors Guild v. Google: Questions and answers.” In: AG. Hozzáférés: 2021. 04 06. https://www.authorsguild.org/authors-guild-v-google-questions-answers/

6 Baucom, Erin. „A brief history of digital preservation.” In: Myntti, Jeremy - Zoom, Jessalyn (ed.): Digital preservation in libraries. Preparing for a sustainable future. Chicago: American Library Association (An ALCTS monograph) 2019. 3 -19. Hozzáférés: 2021. 04 06. Digital Preservation in Libraries: Preparing for a Sustainable Future (An ALCTS Monograph) | ALA Store

7 „Digital Preservation” (Library of Congress) Hozzáférés: 2021. 0406. https://www.digitalpreservation.gov/

8 „A national library for everyone. Digitisation of the collection is creating new opportunities for public enlightenment and widespread access to knowledge and information. Through our online digital library, Nasjonalbiblioteket aims to offer a modern, user-focused service providing democratic access to our collection. Nasjonalbiblioteket is putting in place agreements with rights holders to allow us to make copyright-protected material available as well." Hozzáférés: 2021.0406. https://www.nb.no/en/strategy

9 „...Amazon to have the power to unilaterally force libraries to stay in the 20th century. It's a price we pay for letting Big Tech get so big."

Fowler, Geoffrey A. „Want to borrow that e-book from the library? Sorry, Amazon won't let you.” The Washington Post. March 10, 2021. Hozzáférés: 2021. 0406.

https://www.washingtonpost.com/technology/2021/03/10/amazon-library-ebook-monopoly/ 
Association of Research Libraries (ARL) statisztikai adatai szerint - a beszerzési kiadásokban az időszaki kiadványokra fordított összeg 1998 és 2018 között 166\%-kal nőtt, miközben a monográfiák esetében csak 23\%-kal. ${ }^{10}$

Az elektronikus könyvek könyvtári kölcsönzését a kiadók határozzák meg, megszabva a kölcsönözhető múvek körét, hogy a könyvet hány olvasó kaphatja meg egyidejúleg, hányszor és mennyi ideig lehet kölcsönadni, és hogy a mú bekerülhet-e a könyvtár állományába vagy törlődik a kínálatból stb. Az amerikai könyvtárosszervezet (American Library Association - ALA) hosszú évek óta küzd az öt legnagyobb kiadóval (Big Five) ${ }^{11}$, hogy a könyvtárak korlátozásoktól mentesen kölcsönözhessenek elektronikus könyveket, hasonlóan a fizikai hordozókhoz. A kiadók láthatólag az új technológia valamennyi előnyét a maguk javára kívánják fordítani, sőt, még a törvényességen is túllépnek (pl. árkartell). ${ }^{12} \mathrm{~A}$ könyvtárosszervezet ezért az \#eBooksForAll keretében támogatókat gyűjt, és kész jogi eljárást kezdeményezni a digitális piac monopolizálása ellen (antitrust). ${ }^{13}$

Az Amazonnál például 2011-ben indult Kindle Lending Library, mely 2021 januárjában megszűnt, de helyette ajánlja a cég a 2016-től működő Prime Reading szolgáltatását több mint 1000 könyvvel és folyóirattal, vagy a 2014-es alapítású Kindle Unlimited ${ }^{14}$ előfizetését (havi 9,99\$), mely kétmilliónál több múvet kínál (könyvek, folyóiratok, hangoskönyvek stb.).Avállalatnak természetesenvan hasonlózeneiés videószolgáltatása, $s$ használt könyveket is forgalmaz. Az Amazon Publishing, melyhez több könyvkiadó tartozik, nem adja el a könyvtáraknak az e-könyveit, megakadályozva azok könyvtári kölcsönzését. A vállalat kinyilvánított célja olyan - úgymond - megközelítés kidolgozása, amely egyrészről az olvasóközönség bővítését és a könyvtárhasználók szolgálatát, másrészról a szerzők érdekeinek érvényesülését és a jogdijakat, jövedelmeket egyaránt biztosítja. ${ }^{15}$

\section{Online szolgáltatások}

Akönyvtárirendszernélkülözhetetlen szolgáltatásai közétartozikaközös-,illetveközponti katalógus, amely tartalmazza a lelőhelyadatokat is. A könyvtárak együttműködésével készülő leghíresebb, számítógépes közös katalógus az Ohio College Library Center

10 „ARL Statistics Survey Statistical Trends.” In: Association of Research Libraries. Hozzáférés: 2021. 04 06. https://www.arl.org/arl-statistics-survey-statistical-trends/

11 Az öt nagy kiadó: Hachette, HarperCollins, Macmillan, Simon \& Schuster és a Penguin Random House

12 Albanese, Andrew „Amazon hit with e-book price fixing suit.” Publisher Weekly. Jan 14, 2021 Hozzáférés: 2021. 04 06. https://www.publishersweekly.com/pw/by-topic/industry-news/ publisher-news/article/85318-amazon-hit-with-e-book-price-fixing-suit.html

13 American Library Association. „The State of America's Libraries 2020. A report from the American Library Association." Steve Zalusky, ed. 2020. 24. Hozzáférés: 2021. 04 06. http://www.ala.org/ news/state-americas-libraries-report-2020

14 „Kindle Unlimited” (Amazon) Hozzáférés: 2021. 04 06. https://www.amazon.com/gp/feature. html?docld=1002872331\#faq/ref=insider_ar_reading_primereading

15 Fowler (2021) 
(OCLC) 1967-ben indult, s ma 107 országból való $15.637^{16}$ tagintézményének munkáját összefogva készíti és szolgáltatja a WorldCat nevű katalógust, mely közel 500 millió bibliográfiai rekordot tartalmaz.

Ohio államban a könyvtárak együttmúködéseként 1992-ben jött létre az Ohio Library and Information Network (OhioLINK) ${ }^{17}$, mely 1997-tól a világhálón múködik. Az OhioLINK küldetésében kertelés nélkül, világosan megfogalmazták a célt: az állam felsőoktatása számára teremtsen versenyelőnyt azzal, hogy együttműködve és költséghatékonyan megszerzi és rendelkezésre bocsájtja a folyamatosan gyarapodó, nyomtatott és digitális, tudományos forrásokat, a tanítás, a tanulás és a kutatás előrehaladása, továbbá Ohio tudásalapú gazdaságának növekedése érdekében. ${ }^{18}$

A hazánkban 2001-ben 15 könyvtár közremúködésével létrejött a Magyar Országos Közös Katalógust (MOKKA). A MOKKA az elmúlt húsz évben számos területen ért el igen komoly eredményeket, de az OCLC-hez hasonló, az állam gyűjteményeit oly teljességgel átfogó közös katalógust nem sikerült kiépíteni. A tudás- és információmegosztás érdekében létrehozott könyvtári hálózat, amelynek keretében együttmúködnek az ország tudományos intézményei, ugyancsak várat magára. ${ }^{19}$

A tudományos szakkönyvtárak és a felsőoktatási könyvtárak kiemelt szolgáltatásai közé tartozott az 1970-es évektôl az online adatbázisokban való szakértói keresés. Az 1990-es évek végére a nagy szakirodalmi adatbázisok kialakították a webes felületüket, aminek következtében a könyvtárosok elsődleges feladata azt lett, hogy a kutatókat és a hallgatókat fölkészítésék az adatbázisban való keresésre. Ezek a kurzusok a felsőoktatásban fokozatosan kötelezővé váltak, a kutatástámogatás viszont egyre szűkebb, de szakmailag és tudományosan sokkal igényesebb szolgáltatássá vált.

Az internetes majd webes források közötti eligazodást már a kezdetektől segíteni kívánták a könyvtárosok. A meglehetősen különböző forrásokat, weboldalakat megpróbálták könyvtárrá szervezni: minőségi kritériumok szerint szigorúan átválogatva, $\mathrm{s}$ alapos formai és tartalmi feldolgozással lehetővé tenni a sokszempontú keresést. Az Internet Public Library (IPL) például a michigani egyetem könyvtároshallgatói munkájaként indult 1995-ben. ${ }^{20} \mathrm{~A}$ webböngészők versenye és az anyagi támogatás megszűnése miatt az IPL

16 OCLC. „About.” Hozzáférés: 2021. 04 06. https://www.oclc.org/en/about.html?cmpid=md_ab

17 Mares, Halle. „OhioLINK's 25th anniversíry 1992-2017. A concise history.” [2017] Hozzáférés: 2021. 04 06. https://www.ohiolink.edu/sites/ohiolink.edu/files/uploads/25th\%20Anniversary\%20 History\%20Booklet.pdf

18 „OhioLINK Mission.” In: https://www.ohiolink.edu/content/ohiolink_mission

19 Vö. Az Elektronikus Információszolgálatást Nemzeti Program (EISZ) nemzeti licenc vásárlásával nyújt hozzáférést elektronikus tudományos tartalmakhoz az intézmények meghatározott köre számára. http://eisz.mtak.hu/index.php/hu/informaciok.html

20 Abels, Eileen G. „Transforming the internet public library into the ipl2 virtual learning laboratory." Reference Librarian, 52. 4.sz. (2011) 284-290. doi:http://dx.doi.org/10.1080/02763877.2011.586 $\underline{922}$ 
2015-ben befejezte múködését. ${ }^{21}$ A vállalkozásnak azonban olyan jól csengő neve volt, hogy a Barnes \& Noble Education megvette, de a szolgáltatás tartalmát megváltoztatva, 2020-tól a diákok számára több mint fél millió esszét kínáló portálként működteti.

Hazánkban az Országos Pedagógiai Könyvtár tervezte, hogy magyar iskolai könyvtárak munkáját egy közösen épített Web Iskolai Könyvtárral (WebIK) segíti. A végül pályázati pénzből megvalósult WebIK 2010 és 2015 között müködött, s hasonlóképpen a pénzhiány miatt maradt abba. Ma már ilyen átfogó munkára a könyvtárak nem vállalkoznak, de minden rangos felsőoktatási intézmény könyvtára állít össze listát az egyetemi polgárok számára az online elérhető adatbázisokról, tematikus portálokról, jól használható forrásokról.

\section{A könyvtári szolgáltatások iránti igény megváltozása}

A tájékoztató szolgálatot - az ARL adatai szerint - 2018-ban 1998-hoz képest 84\%kal kevesebben keresték meg, és a kölcsönzések száma is több mint kétharmad résszel esett vissza. A könyvtárközi kölcsönzés 2009-ig folyamatosan nőtt (59\%), majd ekkortól csökkent, és 2018-ra már csak 15\%-kal haladta meg a húsz évvel korábbi szintet. A hallgatóknak tartott csoportfoglalkozások száma viszont látványosan nőtt, 2016-ra 88\%-kal, 2018-ban pedig 67\%-kal haladta meg a kiinduló szintet, s a résztvevők száma pedig folyamatosan gyarapodott (41\%). ${ }^{22}$

A tájékoztatás iránti igény csökkenéséhez hozzájárult, hogy az adatbázis-forgalmazók kifejlesztették az ilyen irányú szolgáltatásaikat: használóképzés (személyes, online, Youtube-anyagok, webinárium stb.), tájékoztató szolgáltatás (telefon, ímél, cset, közösségi háló stb.), sőt tudományos konzulens rendelkezésre bocsátása. Az óriásvállalatok mindegyike olyan portál fejlesztésén dolgozik, amelyről a legkülönbözőbb referensz és teljes szövegú adatbázisok éppúgy elérhetők, mint tudományos hírek, rendezvények, virtuális közösségi terek, ingyenes források stb., de igénybe lehet venni a használatot messzemenően támogató szolgáltatásokat is. Mindez jelentősen szúkítette a könyvtárak adatbázis-keresésben és a kutatástámogatásban betöltött szerepét.

A könyvtári foglalkozások, a könyvtárak oktatási tevékenységei iránt viszont nőtt az igény. Ez összhangban áll azzal a folyamattal, melynek során az információs múveltség (information literacy) megszerzése a felsőoktatás valamennyi szintjén elvárás lett. A képzés egészét átfogó szabályozás 2000 -től indult, ${ }^{23}$ majd elkészült tudományáganként

21 Janes, Joseph. „A fond farewell to the Internet Public Library.” In: American Libraries. RIP IPL. Posted November 13, 2014 Hozzáférés: 2021. 0406.

http://www.americanlibrariesmagazine.org/article/rip-ip|

22 „ARL Statistics Survey Statistical Trends.” In: Association of Research Libraries. Hozzáférés: 2021. 04 06. https://www.arl.org/arl-statistics-survey-statistical-trends/

23 „Information literacy competency standards for higher education.” 2000. American Library Association. Association of College and Research Libraries. Hozzáférés: 2021. 0406.

https://alair.ala.org/bitstream/handle/11213/7668/ACRL\%20Information\%20Literacy\%20 Competency\%20Standards\%20for\%20Higher\%20Education.pdf?sequence=1\&isAllowed=y 
is, ${ }^{24}$ 2006-ban pedig rendezték a könyvtárosok oktatói státuszát ${ }^{25}$ a felsőoktatásban. Az információs múveltség átadásán túl igény mutatkozik a tudományterületek tájékoztató eszközei, illetve adatbázisai bemutatására, valamint a nyílt hozzáférésű platformok használatának és a publikációk megjelentetésének segítése iránt.

\section{Tudományos közlemények nyílt adatbázisai a világhálón}

A felsőoktatási és a tudományos szakkönyvtárak gyűjteményének és szolgáltatásainak igénybevételét jelentősen csökkenti, hogy egyre növekvő számú forrás érhető el szabadon az online térben. Például Paul Ginsparg fizikus 1991-ben létrehozta a tudományos közlemények nyílt hozzáférésű tárát, az arXiv-ot. Mára már a diszciplínák és a kutatási területek preprint-adatbázisai, -szerverei ugyanúgy a szakterület tudományosságának nélkülözhetetlen attribútumai közé tartozik, mint a XIX. században az akadémiai folyóiratok. A tudományos ismereteket előállító intézményekkel szemben általános elvárássá vált, hogy saját anyagaikból, nyílt hozzáférésű repozitóriumo(ka)t alakítsanak ki.

A világhálón föllelhető tudományos közlemények visszakeresésére a Google külön szolgáltatást indított 2004-ben Google Scholar néven. Az elérhető tartalmak szélsőséges bírálói szerint, a használó nem tudhatja, hogy a szolgáltatás jelmondatának megfelelően éppen egy óriás vállán áll vagy „halkan belelépett” (vö. ragadozó-folyóiratok). A Google Scholar közölte bibliometriai adatok azonban, összevetve a tudományosan elismert hivatkozási adatbázisok - Web of Science, Scopus - értékelésével relevánsnak bizonyultak. ${ }^{26}$ Ez más cégeket is arra ösztönöz, hogy kiépítsék a saját vállalkozásukat. A Microsoft 2016-tól szállt be az üzletbe, s elindította a Google Scholarhoz hasonló Microsoft Academic nevű szolgáltatását.

Összegezve megállapítható, hogy a könyvtárak ellenőrzött, hiteles forrásaival szemben ott áll a világháló hihetetlen információbősége, a könyvtári tájékoztatással, kutatástámogatással szemben pedig a keresés szabadságának érzése és saját ítéletünkbe, tudásunkba vetett bizalom.

24 Például a természet- és mérnöki tudományok oktatásához: „Information literacy Standards for Science and Engineering/Technolog", American Library Association, July 24, 2006. http://www.ala. org/acrl/standards/infolitscitech. Hozzáférés: 2021. 04 06. Document ID: b65e0fb0-5ded-a6d42d06-d3cb068960af

25 „ACRL Standards for Faculty Status for Academic Librarians”, American Library Association, September 6, 2006. Hozzáférés: 2021. 04 06. http://www.ala.org/acrl/standards/standardsfaculty [2021. 04. 24] Document ID: 5cb594d4-66de-4ee4-159b-38e1e71288f8

26 Li, Jie, Burnham, Judy F., Lemley, Trey \& Britton, Robert M. „Citation analysis: Comparison of Web of Science, Scopus, SciFinder, and Google Scholar." Journal of Electronic Resources in Medical Libraries, 7. 3.sz. (2010). 196-217. doi: http://dx.doi.org/10.1080/15424065.2010.505518

Bar-llan, J. "Citations to the "introduction to informetrics” indexed by WOS, Scopus and Google Scholar." Scientometrics, 82. 3.sz. (2010) 495-506. 


\section{Merre tartson a könyvtári tájékoztatás és oktatás?}

Általánosan elfogadott, hogyaz ismeretek megszerzéséhez és megosztásához kapcsolódó kompetenciák elsajátítása kulcsfontosságú, akár az információ (information literacy) akár a digitális technológia (digital literacy) felöl közelítünk. Birger Hjørland fölhívja a figyelmet, hogy az információs műveltség és a digitális műveltség közös, központi eleme az ismeretek létrehozásának kritikai értelmezése és az a tudás, mely képessé tesz az információk megítélésére. ${ }^{27}$

Az UNESCO a média- és információs műveltséget az alapvető emberi jogok részének tekinti, amely az információkhoz való megfelelő hozzáféréssel együtt a társadalmi egyenlőség érvényre juttatásának előfeltétele. ${ }^{28} \mathrm{~A}$ szervezet nevesíti is a könyvtárakat, amelyek közremúködése nélkülözhetetlen ezen ismeretek átadásában, valamint a média- és tartalomipar működésének megismertetésében. Azt jelölve meg célként, hogy az információhoz, a tudáshoz való hozzáférésben az igazságosság elve érvényesüljön, mind a társadalmon belül, mind a globális világ társadalmai között.

A másik vonatkoztatási pont az ún. digitális intelligenciához tartozó kompetenciák, amelyeket az Organisation for Economic Co-operation and Development (OECD) közreműködésével az Institute of Electrical and Electronics Engineers (IEEE), a világ egyik legnagyobb mérnöki szervezete dolgozta ki. ${ }^{29} \mathrm{~A}$ digitális intelligencia azokat a technikai, kognitív, metakognitív és szocio-emocionális kompetenciákat fogja át, melyek lehetővé teszik az egyénnek, hogy a digitális élet kihívásaival szembenézzen és alkalmazkodjon hozzájuk. ${ }^{30} \mathrm{~A}$ meghatározásban szerepel, hogy ezek a kompetenciák egyetemes értékeken alapulnak, de részletesen nem fejtik ki, s csak az "oktatásipari” (educational industry) vonatkozásokra történik utalás, a könyvtárakhoz való viszonyra azonban nem.

Sokan tartanak attól, hogy a tartalomipar szolgálatába állított könyvtári tájékoztatás már nem a szellemi szabadság elvét fogja szem előtt tartani, mert a fogyasztó, adott termékkínálatból való választásának segítése lesz a feladata. A digitális kompetenciáknak pedig nem arra kell irányulniuk, hogy az egyén hogyan állítsa céljai szolgálatába a technológiát, hanem hogy alkalmazkodni tudjon digitális világhoz, elsajátítsa a jogszerü és etikus fogyasztói magatartást (vö. Aaron Swartz vs JSTOR).

27 Hjørland, Birger. „Information literacy and digital literacy." PRISMA.COM. 7. (2008) Hozzáférés: 2021. 04 06. http://www.competenzedocenti.it/Documenti/competenze_digitali/information_ literacy_and_digital_literacy_en_es.pdf

28 "Global media and information literacy assessment. Framework: country readiness and competencies." Paris: UNESCO, 2013. Hozzáférés: 2021. 04 06. https://unesdoc.unesco.org/ ark:/48223/pf0000224655

29 Park, Yuhyun „DQ. Digital intelligence. Global standards report 2019. Common framework for digital literacy, skills and readiness." (s.I.) 2019. DQ Institute. Hozzáférés: 2021. 0406.

https://www.dqinstitute.org/wp-content/uploads/2019/11/DQGlobalStandardsReport2019.pdf

30 „IEEE 3527.1-2020 - IEEE Standard for Digital Intelligence (DQ)--Framework for Digital Literacy, Skills, and Readiness." In: IEEE Standards Association. Hozzáférés: 2021. 0406.

https://standards.ieee.org/standard/3527_1-2020.html 
Vajon a könyvtári oktatás feladata-e annak tudatosítása, hogy a böngészők megosztotta ingyenes tartalmaknak és kommunikációs szolgáltatásoknak, a közösségi kapcsolattartásnak mi az ára? Elvárható-e a könyvtártól annak bemutatása, hogyan válnak az egyén személyes adatai és a viselkedését leíró adatok áruvá, s miként használhatók azok a viselkedés előrejelzésére és módosítására, vagy akár az egyén gondolkodásának megváltoztatására? Ugyancsak kérdés, hogyan határozzák meg a XXI. század uralkodó eszméi a könyvtárak társadalmi szerepét, például a platformkapitalizmusról vagy a felügyeleti kapitalizmusról ${ }^{31}$ szóló, új elméletekben.

\section{Záró gondolatok}

A számítógépes adatbázisokat és a digitalizációt a könyvtárak abban a hitben támogatták, hogy ezzel - küldetésükhöz híven - a szellemi javakhoz való hozzáférést szolgálják. A 2000-es évek második évtizedére azonban egyértelmúvé vált, hogy az átadott javak nem a közt, hanem a tartalomipari és információtechnológiai cégeket szolgálják.

Láttuk, hogya cégek azáltaluk forgalmazott digitális múvek, illetve az online szolgáltatások könyvtári beszerzését és terjesztését egyre szigorúbban szabályozzák, sőt, korlátozzák. A fizikai hordozón forgalmazott múvektől eltérő eljárásrendet, különös módon a szerzői jogok és ahhoz kapcsolódó jövedelmek védelmével szokták igazolni.

Mindezzel egyidejúleg ezek az óriásvállalatok a legismertebb könyvtári szolgáltatásokhoz - mint a kölcsönzés, tájékoztatás - hasonló szolgáltatásokat üzemeltetnek. A technológia révén tehát, új életre kelt a fizetős kölcsönzés, s egyre nagyobb teret nyernek az előfizetéses tartalomszolgáltatások és az ún. streaming media.

A kiadók és a forgalmazók - úgy túnik - készek a legvégsőkig elmenni az új technológia adta lehetőségek kiaknázásában. És ami nem elég nyereséges vagy a rászorulókat segíti, azt kell közpénzből fenntartani. A könyvtárak azonban nem válhatnak információs népkonyhává, ahol az adatokhoz, információkhoz való egyenlő hozzáférés elrejti azt, hogy nincs egyenlőség, mert a jelentős információkhoz vagy a fontos ismeretekhez nem lehet hozzáférni.

Ha a szellemi örökségünk védelmét, a tudományos eredményeink számba vételét, a felsőoktatás és a kutatás információellátását, valamint a nemzet tudásvagyonával való gazdálkodást tekintjük, akkor föltehető a kérdés, hogy a globális óriásvállalatok vagy egy országos könyvtári rendszer lássa-e el a feladatokat. Ugyanennek a problémának egy másik vetülete a könyvtári oktatás tematikája: az információhoz, az ismeretekhez való hozzáférés álljon-e középpontban vagy pedig az, hogy az egyén a „digitális élet kihívásaival szembenézzen és alkalmazkodjon hozzájuk".

Vajon az eszmék és gondolatok sokféleségének megismerésén, valamint a tudás lehetőleg a társadalom egésze számára hozzáférhetővé tételén alapuló könyvtárfelfogás érvényes lesz a 21. században?

31 Zuboff, Shoshana „The age of surveillance capitalism. The fight for a human future. At the new frontier of power." New York: 2019. PublicAffairs 